\title{
1. The analytic lens
}

'Law and society', as a terminology, denotes a relationship between the two. Over the years, what kind of relationship 'law' and 'society' have whether society manifests in law, whether law shapes society, or whether they have reciprocal influence - has been the subject of numerous academic discourses. Although Chinese 'law' tends to evoke uncertainty, perplexity or even disapproval among Anglo-American and European jurists, China, being one of the ancient civilizations and having almost 4,000 years of written history, ${ }^{1}$ is an excellent case study of the interplay between 'law' and 'society'. Given the fact that 'law and society' is a multifaceted research field, it is imperative to explain the analytic lens, and to define the parameters, of the present study before delving into in-depth discussion.

\section{WHAT ARE 'LAW' AND 'SOCIETY'?}

The study of 'law and society' evidently concerns the relationship between 'law' and 'society'. In this respect, two fundamental questions arise: 'what does law mean?' and 'what is a society?'. There have been countless scholarly attempts to define these two terms, but the definitions generated largely depend on the respective disciplines of the researchers and what methodologies they have employed. Although the present study does not endeavour to define these two terms and add new contributions to the existing literature, it would be judicious to first highlight how prominent thinkers and scholars have defined these two terms and then put forth working definitions for the discussion of the relationship between 'law' and 'society' in China. The following sections, therefore, will first discuss the less controversial term 'society' and then the more contentious term 'law'.

1 www.gov.cn (2005). 


\section{The Social Milieu}

The question of 'what is a society?' is seldom posed in daily life because most people intuitively have an impression of what a 'society' is. Analytically, the simplest view is that the interactions of individuals, who are the basic constituents of a 'society', form a group, while the interactions of groups lead to the creation of a 'society'. Indeed, the word 'society' is derived from the Latin word socius, which conveys a sense of association, fellowship, comradeship, alliance or union. However, not all interactions between individuals and groups will form 'societies'. Over the years, what constitutes a 'society' and how 'society' operates have been the research topics of many academic studies. ${ }^{2}$

Depending on the relevant discipline, 'society' has been classified on various bases: primary means of subsistence (such as hunting-gathering societies, horticultural societies, pastoral societies, agrarian societies and industrialized societies); political structure (such as bands, tribes, chiefdoms, fiefdoms and states); geographical location (such as European societies, African societies and Asian societies); evolution of legal system (such as primitive societies, traditional societies and modern societies); and a combination of factors, including technological advancement and resource distribution (such as pre-industrial societies, industrial societies and post-industrial societies). ${ }^{3}$ Although a pastoral society is often a tribal society, these classifications do not necessarily reflect parallel developments because a state can be a traditional society.

This taxonomy of 'society' has generated numerous definitions of 'society'. Notwithstanding a wide variety of definitions, a human 'society' has several essential characteristics, including likeness, ${ }^{4}$ consciousness of kind, ${ }^{5}$

2 E.g., MacIver and Page (1949); Parsons (1966); Durkheim (1984).

3 In a post-industrial society, instead of the production of goods, the main industries are information, services and high technology. Moreover, knowledge has become a significant factor in the creation of wealth.

4 MacIver (1931). Likeness or mutuality generates relations among individuals or groups who have the same or similar characteristics or conditions, such as the same or similar faith, ethics, lifestyle, cultural dispositions, customary practices, language and living environment.

5 Giddings (2014). 'Consciousness of kind' refers to reciprocal awareness, which, in turn, engenders feelings of association, fellowship, belonging and union. 
differences, ${ }^{6}$ conflicts, ${ }^{7}$ interdependence, ${ }^{8}$ cooperation, ${ }^{9}$ a social structure and a defined territory. ${ }^{10}$ Moreover, since social relations change and society evolves over time, 'society' is not static but a dynamic, organic whole. For instance, Auguste Comte, the pioneer of sociology, defined 'society' as a 'social organism' having a harmony of structure and function. ${ }^{11}$ Morris Ginsberg, who played a key role in developing the discipline of sociology, defined 'society' as 'a collection of individuals united by certain relations or modes of behaviour which mark them off from others who do not enter into these relationships or who differ from them in behaviour' ${ }^{12}$ Maclver and Page depicted 'society' as 'a web of social relationships', ${ }^{13}$ which is ever-changing.

Apart from the basic characteristics, sociologists have developed typologies for theoretical analysis. For instance, Ferdinand Tönnies argued that there are two basic types of social groupings - Gemeinschaft (community) and Gesellschaft (society). ${ }^{14}$ Members in Gemeinschaft are bonded together by shared beliefs, values and traditions generated from direct personal interactions. Following the Wesenwille ('essential will'), members see themselves as an avenue to serve the goals of the grouping. A family or a religious institution is a common example of Gemeinschaft. In contrast, members in Gesellschaft form purposive and impersonal relationships through indirect interactions. Following the Kürwille ('arbitrary will'), members consider the grouping a means to advance individual goals. A city or a state is an excellent example of Gesellschaft. As such, a developmental trend of Gemeinschaft to Gesellschaft can be exemplified by the transformation of a rural, 'collective' society into an urban and 'individualistic' society. In this connection, some Asian

6 Durkheim (1984). Members of a society have different personalities, capabilities, skills and talents, which results in the social division of labour and specialization of roles.

7 Simmel (1964). A society is comprised of individuals with various kinds of differences, so conflicts will inevitably arise.

8 Members of a society cannot live alone. Individuals depend on others for food, shelter and other needs.

9 Gisbert (1973). Since individuals have different needs and desires, cooperation is indispensable for a society to exist and survive.

10 A social structure is composed of interactive social institutions, such as familial, cultural, educational, economic, legal, political and religious institutions.

11 Comte (1875), 65-66.

12 Ginsberg (1950), 40.

13 MacIver and Page (1931), 6.

14 Tönnies (1963). 
countries, such as China, Japan and Korea, are often regarded as 'collective' societies because the existence and well-being of the grouping are deemed more important than those of an individual member.

Furthermore, two diametric paradigms - conflict theory and consensus theory - are extensively used to analyse 'society'. The former refers to a society in which clashes abound due to the availability of limited resources and the tendency of its members to maximize interests. Given that social order is maintained by the manipulation and coercion of the dominant and powerful groups through the establishment of institutions, social changes can occur only through struggles between classes. Karl Marx is a representative of the conflict theorists. ${ }^{15}$ Conversely, the latter refers to a functionally integrated society based on a shared culture and a consensus of fundamental values and norms. Since there is a collective consensus, clashes arise only at the personal level. The societal focus is to maintain social stability, while changes may occur slowly within the limits of consensus. Talcott Parsons, who likens 'society' to a biological organism, belongs to the consensus camp. ${ }^{16}$ Consequently, conflict theory emphasizes social class, whereas consensus theory focuses on social status. In this regard, it is noteworthy that countries with a Confucian heritage, such as China, Japan and Korea, are often viewed as 'consensus' societies.

In any society, while resemblances and similarities beget harmony, differences engender disparities and conflicts. Thus, it can be argued that a particular society is a primarily discordant society because its constituents are socially divisive and conflicts are fought out rather than peacefully resolved, or alternatively, that a society is a largely harmonious society because its constituents are socially integrated and conflicts are resolved through negotiation and cooperation. Similarly, it can be argued that a society is a primarily collective society because decisions are made in the light of the possible impact on society, or alternatively, that a society is a principally individualistic society because individual rights and freedoms are highly valued. This way of thinking may avert a polarized assessment of 'society' based solely on the conflict or consensus paradigm or the collective or individualistic divide. For this reason, the present study will not apply one analytic paradigm to the exclusion of the other.

\footnotetext{
5 Marx and Engels (2012).

16 Parsons (1964).
} 
For the purposes of the present study, a 'society' refers to a group of persons who are alike in most aspects but different in some respects, ${ }^{17}$ live in a certain geographical area, espouse the same cultural and ethical values, practise division of labour and specialization of roles, ${ }^{18}$ cooperate and resolve conflicts for mutual survival, and interact with one another based on commonly shared norms and expectations. Since a society evolves over space and time, different societies may exist throughout history. In any society, when social relations have become more complex, economic activities have diversified, and the unequal distribution of wealth has resulted in social stratification, the exigence of social governance will inevitably arise. Indeed, societies have adopted different systems of social governance, one of which is to impart to law the central role.

\section{The Legal Labyrinth}

'What is law?' is the mainstay of jurisprudence. Many philosophers and jurists have attempted to define 'law', but what 'law' is, or what the content of 'law' should be, hinges on the creed of, or the perspective adopted by, the interpreter. From ancient times to modern days, the definition of 'law' is primarily derived from how normativity, morality, reason, authority and coercion have been individually or jointly underscored. Although 'law' can be broadly defined as an institution or a system comprised of the legislature, legal texts, courts, tribunals, judges, lawyers and enforcement agencies, 'law' is often narrowly referred to as legal rules. In the latter case, 'law' has been defined and categorized in both general and specific terms. At the general level, 'law' has been defined through an inquiry as to its nature. At the specific level, 'law' has been categorized with reference to its sources or forms, ideological foundation, jurisdictional scope, and functions or purposes. Based on the nature of law, two schools of thought - natural law theory and legal positivism - have dominated the scene.

According to natural law theory, law and morality are essentially connected. An unjust law is not a true law, in which case there is no need to obey it. The laws of nature are superior to legislation made by human beings, and reasoning will reveal the laws of nature. For instance, Cicero believed that 'law is the highest reason, implanted in nature which orders

17 MacIver (1929). MacIver stated that "primary likeness and secondary differences create the greatest of all social institutions - the division of labour'. ibid., 2 .

18 Durkheim (1984). 
those things that ought to be done and prohibits the opposite';19 that 'law was not thought out by human intellects; it is not some resolution of people, but something eternal that rules the whole universe through the wisdom of commanding and prohibiting'; ${ }^{20}$ and that 'law is distinction between just and unjust things, modelled on nature, the most ancient and chief of all things'. ${ }^{21}$ In other words, law, which is made by God and is universally applicable, can be discerned through the application of reason. Similarly, St Thomas Aquinas maintained that there are four categories of 'law': (1) eternal law known only to God; (2) natural law that can be discerned by reason; (3) divine law revealed in the scriptures; and (4) human law, which is "nought else than an ordinance of reason for the common good, made by the authority who has care of the community, and promulgated'. ${ }^{22}$

The divine authority of natural law was challenged by Hugo Grotius, who suggested that natural law is founded on reason applied to human nature alone. ${ }^{23}$ Coupled with the increasing attention to the value of the individual in his times, this new perspective transformed the natural law theory with a divine orientation into the natural rights theory based on individual rights. ${ }^{24}$ Despite the secularization of natural law, morality and application of reason are still the cornerstones of natural law/natural rights theory. For example, Immanuel Kant, who conceived the concept of categorical imperative, avowed that a moral imperative based on reason requires laws to 'be chosen as though they should hold as universal laws of nature'.25 Lon Fuller also argued that 'law' has an 'inner morality', namely, there is a necessary connection between law and morality, without which it is not 'law'. ${ }^{26}$ Focused on 'the common good', John Finnis defined natural law as 'the set of principles of practical reasonableness in ordering human life and human community', ${ }^{27}$

On the other hand, legal positivism is premised on the separation of law and morality. According to positivists, 'law' consists of clearly defined rules enacted by a sovereign or legislature. Moreover, the validity

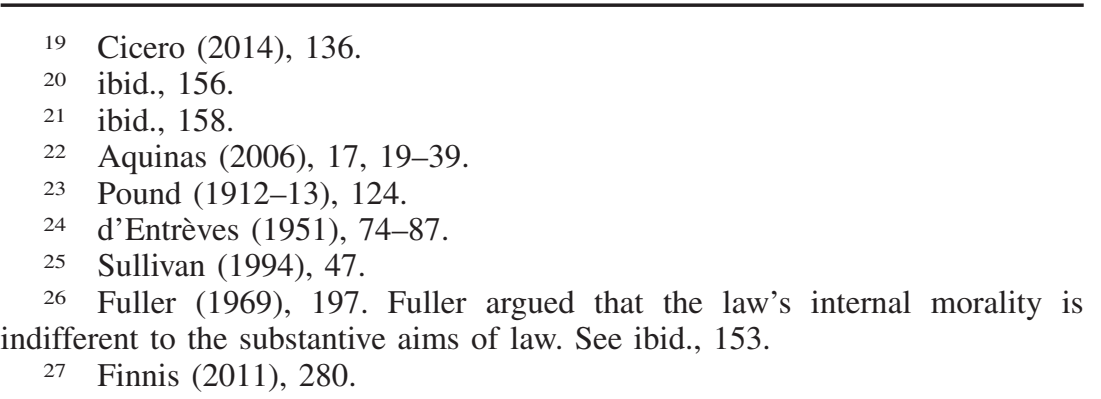


of 'law' should not be linked to moral rectitude, even though 'law' can be influenced by morality and custom. Furthermore, the source of 'law' should be objectively traceable. For example, the Romans regarded 'law' as an expression of the will of the Roman people or of the Emperor to whom the people had transferred power, even though the distinctions between ius civile (the codes of states), ius gentium (the laws of nations), and ius naturale (the laws of nature) were recognized. ${ }^{28}$ Thomas Hobbes maintained that 'law' is a command of the sovereign, the sovereign is above the law, but the people have the right to replace the sovereign if he fails to secure a peaceful social order. ${ }^{29}$

In the nineteenth century, jurists began to refer to legal positivism as the imperative theory of law - laws as commands issued by the sovereign. Jeremy Bentham, a leading figure of utilitarianism, argued for the separation of law and morality and sought to codify the common law due to its indeterminacy. ${ }^{30}$ Although John Austin acknowledged the existence of God's divine law, he defined 'law' as a body of rules fixed and enforced by political superiors. ${ }^{31}$ Austin also pointed out that morality and custom can be 'clothed with legal sanction by the sovereign'. ${ }^{32}$ Moreover, Max Weber averred that 'an order will be called law if it is externally guaranteed by the probability that coercion (physical or psychological), to bring about conformity or avenge violation, will be applied by a staff of people holding themselves specially ready for that purpose'. ${ }^{33}$ According to Weber, 'law' is distinguishable from other normative orders based on three characteristics: (1) pressure to comply due to external actions or threats, (2) involving coercion or force, and (3) from people whose official role is to enforce the law. ${ }^{34}$ In other words, 'law' refers to legislation enacted by a ruler or the state.

Contemporary jurists Hans Kelsen, H. L. A. Hart, Joseph Raz and Ronald Dworkin have further refined or developed legal positivism. Disregarding moral, social and political factors, Kelsen argued that 'law' consists of norms, which carry sanctions for failure to comply with them, and that the validity of all norms is based on a Grundnorm (basic norm), which is a purely formal construct with no specific content. ${ }^{35}$ Hart also

\footnotetext{
28 d'Entrèves (1951), 19.

29 Hobbes (2012), 175-179.

30 Bentham (1996).

31 Austin (1965), 23.

32 ibid., 136.

33 Weber (1954), 5.

34 ibid., 12-20.

35 Kelsen (2005), 8.
} 
explained that 'law' is a system of 'primary rules' (rules of obligation to be obeyed by the people) and 'secondary rules' (rules of recognition, rules of change and rules of adjudication to be accepted and observed by legal officials). ${ }^{36}$ Similarly, Raz stated that (1) law, the ultimate source of authority, is a social fact, (2) legality does not depend on moral merit, and (3) legal systems claim supremacy over other institutionalized normative systems in society. ${ }^{37}$ In other words, 'law' is a set of institutionalized norms supported by state sanction. Ronald Dworkin, however, argued that 'law', as an interpretive concept, includes not only rules that have met the requirements enunciated in the rules of recognition, but also underlying principles, the explication of which will inevitably involve moral or political considerations. ${ }^{38}$

Amid the debate between natural law theory and legal positivism, historicists maintained that 'law' is embedded in the history and culture of a society, that 'law' is not imposed on the populace due to political will or for a moral reason, and that the legal text should be interpreted in the light of the relevant social context. For instance, Friedrich Carl von Savigny, a pioneer of historicism, avowed that (1) 'law' is an expression of the common consciousness of the people (the Volksgeist), (2) there is an organic connection between 'law' and the being and character of the people, and (3) codification, which freezes the development of 'law', should occur only when a society reaches a high level of cultural maturity. ${ }^{39}$ In a similar vein, Henry Sumner Maine explained that (1) legal concepts and institutions are rooted in previous times; (2) 'law' passes through six phases in 'progressive' societies, namely, kingly rule, customary law, codes, legal fictions, equity and legislation; and (3) 'progressive' societies differ from ancient ones by the gradual dissolution of family dependency (civil law based on status) and the growth of individual obligation (civil law based on contract). ${ }^{40}$ For these reasons, the meaning of 'law' cannot be separated from the relevant historical and cultural conditions, and 'law' progresses, or the content of 'law' changes, as society evolves.

Looking beyond legal texts, legal realists argued that 'law' is rationally indeterminate in the sense that the purported legal reasons either do not justify the court decisions or are insufficient to explain why the judges

\footnotetext{
6 Hart (1994), 79-99.

Raz (1979), 116-120, 152.

Dworkin (1986), 45-86.

von Savigny (1831), 24-29.

40 Maine (1986), 3-41, 163-165.
} 
decided as they did. Legal realists claimed that 'law' should be understood as it is practised in the courts, law offices or enforcement agencies. Oliver Wendell Holmes, the pioneer of American legal realism, explained that judges do not deduce legal conclusions by mechanically applying legal principles because when they interpret legal texts or exercise judicial discretion, they are affected by such factors as public policy, political views, personal values and social background. ${ }^{41}$ Hence, he argued that 'the prophecies of what the courts will do in fact, and nothing more pretentious, are what I mean by law' ${ }^{42}$ In a similar vein, Roscoe Pound distinguishes 'law in books' from 'law in action'. ${ }^{43}$ As a result, legal realism focuses on empirical, rather than doctrinal, research and 'law in action' instead of 'law in books' to exemplify the discrepancy between legal theory and legal practice.

Although natural law theory, legal positivism, historicism and legal realism have different theoretical emphases, they all point 'law' in the direction of rules, principles, standards, customs or practices endowed with authority or approval from God, the state or the community, the non-adherence to which will result in immorality, disapprobation, contempt, sanction, punishment or ostracism. The social theory of law argued that 'law' is derived from social practices, but such an explanation has raised the questions of who is to identify a phenomenon as 'law' through social practices and how many people are required to have a behavioural standard identified as 'law'. ${ }^{44}$ Meanwhile, legal pluralists maintained that multiple state legal orders and non-state legal orders or normative customs can operate within a single society. ${ }^{45}$ For example, Eugen Ehrlich distinguishes 'norms of decisions', which are to be enforced by the courts, from 'living law', which is custom or norm that 'dominates life itself even though it has not been posited in legal propositions'. ${ }^{46}$ Nonetheless, legal pluralists formulate competing versions of what 'law' is and are unable to distinguish what is legal from what is social. ${ }^{47}$ In this connection, autopoietic theorists asserted that 'law' can be identified in discourses invoking the binary communicative code of legal and illegal. ${ }^{48}$

\footnotetext{
41 Holmes (1972).

42 ibid., 215.

43 Pound (1910).

44 Tamanaha (2001), 166-167.

45 Griffiths (1986), 3.

46 Ehrlich (2002), 493.

47 Tamanaha (2001), 173-174.

48 Ladeur (1988), 253.
} 
Each of the preceding expositions of 'law' has an ounce of truth. In attempting to define 'law', legal theorists have shifted the source and authority of law from moral reasoning and divine authority, to legislative enactment and state authority, and finally to shared norms and community approval. Hence, a corollary question is whether there exists any common thread among a multiplicity of arguments about 'law'. Apparently, the obligatory nature of 'law' can be discerned among most, if not all, of the diverse views of 'law', that is, the members of the relevant society experience pressure from within (of their own volition) or without (consequential formal sanctions) to conform, whether it is to uphold a right, to perform an obligation or to refrain from deviant conduct. As such, state-formulated legal rules, normative customs, moral precepts and even religious doctrines can be parts of the content of 'law'. Although a normative system and a legal system are not necessarily the same, what has elevated a norm to the status of a state law instead of being merely a custom, moral precept or religious doctrine depends on the relevant economic, social and political contexts. In this light, it is sensible to define 'law' broadly as standards, principles and practices observed by the populace, whether being legal or non-legal, or whether institutionalized or not, such as legislation enacted by the ruler or the legislature and normative customs endorsed by the community.

Adamson Hoebel once said, 'to seek a definition of the legal is like the quest for the Holy Grail'. ${ }^{49}$ Indeed, it is quite easy to get lost in a labyrinth of definitions of 'law'. John Austin, who had a list of what he deemed to be necessary legal concepts, such as right, duty, redress and habitual obedience, argued that only the 'mature' legal systems (Western civil law and common law systems in his times) qualified for inclusion. ${ }^{50}$ Using the presence or absence of legal concepts, principles, processes and institutions associated with Anglo-American and European legal systems without reference to the relevant time and place to determine whether a rule, norm, standard, custom, process or institution is or is not 'law' or 'legal' may lead to the conclusion that some societies, such as Asian or indigenous ones, do not have legal systems. ${ }^{51}$ Indeed, it is notable that scholars of general jurisprudence have attempted to identify and analyse elements and concepts common to all legal systems, but such

\footnotetext{
49 Hoebel (1954), 18.

50 Tamanaha (2001), xv.

51 For example, when British explorers first arrived in Australia, they regarded Australia as terra nullius based on the misconception that the indigenous peoples did not have legal systems.
} 
endeavours have not been successful. ${ }^{52}$ As Brian Tamanaha said, 'law is a thoroughly cultural construct. What law is and what law does cannot be captured in any single concept, or by any single definition. Law is whatever we attach the label law to'.53 As a result, he suggested that 'law' be identified rather than conceptualized, ${ }^{54}$ even though there remains the question of what identifying criteria the 'social actors' should use.

To further complicate the comprehension of 'law', 'law' is categorized with reference to its sources or forms, underlying ideology, jurisdictional scope, and purposes or functions. The sources or forms of law concern the questions of where the law comes from, who makes the law, and how law is made. These kinds of questions have often surfaced in relation to the divide between the civil law tradition and the common law tradition. One oversimplified distinction between the two traditions is the claim that the law in the civil law tradition is comprised of legislation, whereas the doctrine of precedent and the consequential judge-made law characterize the law in the common law tradition. It is evident that the legislatures in both traditions are to enact law, while the executive branch of the government is often delegated with authority to enact administrative regulations or decrees to carry out its mandate. Although there are no case precedents in the civil law tradition, lower courts do often follow the reasoning of higher courts in deciding cases with similar legal or factual issues. Moreover, case law does not constitute the bulk of law in common law countries as evidenced by the vast number of Australian and US statutes. Merryman and Pérez-Perdomo explained that the main difference between the civil law tradition and the common law tradition is their underlying ideologies, namely, the judiciary in the civil law tradition is to apply the law, but not to interpret and make law. ${ }^{55}$ Indeed, with reference to ideology, 'law' has been further categorized into socialist law found on Marxism; Islamic law, or Sharia law, derived from the Koran (Quran); and Talmudic law based on the Old Testament and the law of the Jewish people.

In terms of jurisdictional scope, there is national law and international law. National law, which is often referred to as municipal law or domestic law, regulates the relations and conduct between individuals, entities and the government within the borders of a given state. Within a single legal system, law can be further divided into federal statute,

\footnotetext{
52 Tamanaha (2001), xiii.

53 ibid., 193 (emphasis in original).

54 ibid., 194.

55 Merryman and Pérez-Perdomo (2007).
} 
provincial legislation and municipal ordinance. International law, however, regulates the relations between states, including treaties and customary international rules, as well as transnational activities between individuals and/or entities. Both national law and international law are further subdivided into public and private law. Within a state, public law, such as criminal law and constitutional law, has an impact on the whole society and is applicable to individuals, entities and the government, while private law, such as tort law and contract law, deals with the relations between individuals and/or entities. In the international community, public international law deals with the relations between states, such as the United Nations Convention on the Law of the Sea, whereas private international law, which is often referred to as conflict of laws, concerns activities between private individuals and entities across national borders. Furthermore, an individual may file a lawsuit against another individual for breach of a contract in accordance with the civil procedure law (which is called a civil action), the government may prosecute a suspect for having committed the crime of robbery based on the criminal procedure law (which is called a criminal action), and an individual or entity may file an administrative lawsuit against the government.

Based on its purposes or functions, law can be prescriptive (stating what must be done) and proscriptive (stating what must not be done). For instance, law can be employed to set standards of conduct (such as minimum wages law), protect individual rights (such as freedom of speech), resolve disputes (such as landlord-tenant law), restrain government power (such as constitutional law), and outlaw antisocial behaviour (such as criminal law). Broadly speaking, substantive law creates legal rights and obligations (such as consumer rights and fiduciary duties), whereas procedural law outlines the process with which to protect rights or to enforce obligations (such as filing a consumer complaint and initiating an administrative lawsuit). Indeed, a multiplicity of laws deal with various kinds of economic, political and social activities. For example, administrative law deals with the conduct of government agencies, labour and employment law regulates employment relationships and union activities, criminal law punishes the offender and deters similar antisocial behaviour, and an enabling or implementing statute facilitates the implementation of an international treaty.

In consequence, the question of what 'law' is, or what should be the content of 'law', depends on the context in which the question is raised, even though the aforesaid categories are summarily referred to as 'law'. For instance, the term 'civil law' may refer to a civil law system or the law applicable to a defamation dispute. To understand 'what is law?' 
through an inquiry of its nature is confusing, let alone conceptualizing or classifying 'law' with reference to its sources, ideology, jurisdiction or functions. As a matter of fact, 'law' has both spatial and temporal dimensions because 'law' bears the imprint of a given place and time. The content of 'law' varies from society to society, and the law changes, or operates differently, as society evolves. For example, the rights and duties of the landlord and tenant can be different from country to country, women in previous centuries could not vote, and a married woman in the past could not possess property by herself. For the purposes of the present study, it would be sensible to define 'law' broadly as an institution, rather than narrowly as legal rules, and to expand the parameters of law by including not only the legal norms promulgated and enforced by the ruler or the government through the formal state apparatus, such as the court, police and prison, but also behavioural norms and informal practices observed by the populace with the express or tacit approval of the state.

\section{THEORIES OF LAW AND SOCIETY}

The study of the relationship between 'law' and 'society', whether it is about law as an integral constituent of society, the empirical study of legal rules and processes, or the relevance of law in daily living, has been conducted by scholars in sociology of law, socio-legal study, law and society, sociological jurisprudence, or legal anthropology. ${ }^{56}$ Because 'law and society' is 'an amalgam of law, sociology, political science, anthropology and history, with lesser bits of economics and psychology',57 and the present study does not pursue a general, comprehensive theory on the role of law in society, ${ }^{58}$ the investigation here is a law-and-society, rather than a sociology-of-law or socio-legal, analysis because legal, cultural, historical, political, and economic factors are taken into consideration.

To date, there have been numerous studies to explore, explicate and expound the relationship between 'law' and 'society'.59 How legal theorists and sociologists analyse the role or function of law in society depends on whether they regard the consensus or conflict model as the

56 Sociology of law is an interdisciplinary field focused on the empirical study of law as a social phenomenon. In Europe, it is often referred to as socio-legal study, while in the US, it is usually referred to as law and society.

57 Galanter and Edwards (1997), 379.

58 Friedman (1986), 769.

59 E.g., Habermas (1996). 
more accurate depiction of reality. In a consensus society, the legislature represents the common will, so the law is neutrally administered for the common good. In a conflict society, the law is manipulatively used and enforced to deal with class struggles. Given that the focus of the present study is on Chinese 'law and society', an in-depth discussion of social-legal theories will not be undertaken. Instead, the following highlights only the predominant theoretical perspectives - the evolution theory, functionalism, instrumentalism and critical legal theories.

\section{The Evolution Theory}

Evolution theorists, like historicists, argue that law progressively emerges out of custom. The Greek word nomos initially referred to custom ${ }^{60}$ and sometimes to both custom and law without distinction. ${ }^{61}$ According to Plato, primitive societies are governed by customs, and laws have arisen due to the expansion of society from families and clans to communities with different customs. ${ }^{62}$ Similarly, Aristotle treated law and custom as functional equivalents, even though he lent more weight to the latter. ${ }^{63}$ As previously discussed, Maine explained that law develops in stages, moving from pre-customary law (ad hoc decisions of the sovereign) to customary law (maintained by the aristocrats) and finally to legislation (enacted by the legislators). ${ }^{64}$ This progressive development can be evidenced by the findings that relations in a community are initially governed by status, namely, the identity of a person in relation to his or her group, but later governed by contracts. ${ }^{65}$

In the contemporary US, Paul Bohannan, Philippe Nonet and Philip Selznick are advocates of the evolution theory. Bohannan argued that laws are customs extracted from their normal setting through a process of re-institutionalization, in which specific customs are chosen to become laws that govern all social institutions. ${ }^{66}$ Nonet and Selznick propounded an analytic model comprised of repressive law, autonomous law and responsive law. ${ }^{67}$ More specifically, repressive law is employed by people in power to consolidate authority and command obedience through

\footnotetext{
60 Jones (1956), 34.

61 Foster (1941), 116.

62 Plato (1980), 680a, 681a-d.

63 Anderson (1999), 152.

64 Maine (1986), 4-41.

65 ibid., 165.

66 Bohannan (1965), 34-37.

67 See Nonet and Selznick (1978).
} 
coercion for the preservation of social order. Autonomous law holds officials accountable to the rule of law, emphasizes procedural regularity and predictability, and channels changes through established legal institutions and procedures. Responsive law focuses on the substantive goals of society and views law as an instrument for achieving them. Although a legal order will exhibit elements of all of these three types, its basic posture may approximate one type more closely than the other. ${ }^{68}$ An 'inner dynamic' exists in the legal order to generate pressure for change, thus producing a developmental sequence. ${ }^{69}$ Hence, legal development is social development, and social order is characterized by the order of legal relations. ${ }^{70}$

\section{Functionalism}

Sociological functionalists focus on how social institutions, which are composed of interconnected roles and interrelated norms, contribute to the coordination of behaviour and the maintenance of social order. Plato and Aristotle noted that the fundamental function of law is the maintenance of a good social order, even though laws are often used to preserve the privilege of the ruling elites. ${ }^{71}$ Moreover, Pound explained that the legal order was an ordering of men to keep each in his appointed place in the politically organized society of an ideal Greek city'. ${ }^{72}$

Emile Durkheim, an eminent scholar of social theory, maintained that 'social facts' are the norms, common expectations and behavioural rules that individuals observe as members of a society, and that the disregard of, or indifference to, the 'social facts' will result in 'anomie' (a state of lawlessness). ${ }^{73} \mathrm{He}$ argued that societies are characterized by two types of solidarity - 'mechanical solidarity' and 'organic solidarity'. 'Mechanical solidarity' is found in collective, homogeneous societies that have uniform values and lack significant division of labour (primitive societies), whereas 'organic solidarity' is found in individualistic, heterogeneous societies whose members practise division of labour and are highly interdependent (modern societies). ${ }^{74}$ Moreover, repressive law is found in societies of mechanical solidarity, where crimes undermine the collective

\footnotetext{
68 ibid., 17.

69 ibid., 20.

70 Tamanaha (2001), 34.

71 ibid., 11.

72 Pound (1959), 29.

73 Durkheim (1984), 291-309.

74 ibid., xiv.
} 
ethical values of society and punishment performs a significant role in expressing social disapprobation. ${ }^{75}$ Conversely, disputes in societies of organic solidarity, where adjustments are required in the relations between the wrongdoer and the injured, are to be resolved by restitutive (compensatory) law, and the forms of punishment for having committed crimes diminish in their cruelty. ${ }^{76}$ As the organic society becomes increasingly differentiated and the 'collective conscience' (common awareness and understanding) declines, the function of law is to promote and maintain social cohesion. In a similar vein, Jürgen Habermas stated that 'the constitution of the legal form became necessary to offset deficits arising with the collapse of traditional ethical life'. ${ }^{77}$

Max Weber, another illustrious social theorist, argued that a legal system is 'formal' if the rules and procedures necessary for decision making are available within the system (being self-sufficient), but a system is 'substantive' if it goes outside of law to base decisions on religion, ethics, policy or some other grounds (being ad hoc and outcome-oriented). ${ }^{78}$ Moreover, formal and substantive systems are subdivided into 'rational' and 'irrational' systems. 'Rational' systems rely on logical analysis and the application of rules and principles, whereas 'irrational' systems do not. ${ }^{79} \mathrm{~A}$ formal and rational system is conducive to the development of capitalism in Western societies because it provides the highest degree of stability and predictability for decision making and planning. ${ }^{80}$ Furthermore, people feel obliged to obey the law due to three types of legitimate domination: traditional (the sanctity of long-standing rules), charismatic (the powerful character of an individual) and legalrational (the belief in the legality of enacted rules and the right of the authorities to issue commands). ${ }^{81}$ In this light, a society dominated by a charismatic leader should have a formally or substantively irrational legal system. As a result, Weber tried to explain legal development against the background of the emergence of the middle class and the rise of capitalism.

Likewise, Karl Llewellyn asserted that law serves fundamental functions, which he called 'law-jobs', such as preventing disruptive conflicts

\footnotetext{
75 ibid., 68.

76 ibid., 68.

77 Habermas (1996), 113.

78 Tamanaha (2001), 37.

79 ibid.

80 Weber (1954), 39-40, 228-229.

81 ibid., 334-337.
} 
in society, resolving disputes between members of a society, accommodating social changes, recognizing authority structure, and establishing procedures for performing important tasks. ${ }^{82}$ Hoebel also maintained that law seeks to channel behaviour so as to avoid or prevent conflicts. ${ }^{83}$ Thus, the cardinal function of law appears to be the resolution of disputes. Besides, Llewellyn and Hoebel argued that law has the additional role of cleaning up social messes, so anything that achieves this end should also be regarded as 'law'. 84 As mentioned above, Ehrlich argued that positive legal norms often have little connection to the prevailing social norms, so social order is maintained through the 'living law', which casts doubt on the social ordering function of formal law.

\section{Instrumentalism}

Instrumentalists believe that law is an instrument of social engineering. For example, Bentham argued that law is a social tool to be used by legislators to achieve the greatest happiness of the greatest number of people. ${ }^{85}$ Likewise, Caspar Rudolph Ritter von Ihering asserted that the purpose of law is to secure the conditions of social life, so legal rules are created to serve human purposes, even though this is often forgotten with time or due to mystification by some jurists. ${ }^{86}$ Additionally, public choice theorists maintain that law is the product of the competition between self-serving groups, who pursue legislation favourable to their respective situations, so it is justifiable for the courts to narrowly interpret law which contradicts the public interest. ${ }^{87}$

In fact, Marxists are the frequently cited advocates of instrumentalism. Marx asserted that the totality of production relations constitutes the economic structure of society, on which sits a legal and political superstructure. ${ }^{88}$ The superstructure, in which law is a component, maintains and conceals the relations of class domination. ${ }^{89}$ The essential function of law, therefore, is to maintain order in the interest of the dominant class. ${ }^{90}$ His concept of dialectical materialism is so named

\footnotetext{
82 Twining (1993), 134-136.

83 Hoebel (1954), 36.

84 Llewellyn and Hoebel (1941), 20.

85 King (1986), 4.

86 von Jhering (1968), 345.

87 Farber and Frickey (1991), 17-21.

88 Marx (1859), Preface.

89 Tamanaha (2001), 41.

90 Cotterrell (1992), 106-114.
} 
because the means of production are materially determined and there will be an inevitable conflict between the bourgeois and the proletariat. ${ }^{91}$ After the proletariat has seized the means of revolution and established a dictatorship of the proletariat, law will be instrumentally employed to change moral values and social conduct to accord with socialist ideologies. ${ }^{92}$ In the end, there will be a classless, community society in which law will wither away and social relations will be governed by custom. ${ }^{93}$ In this sense, law is the result of one particular kind of society.

\section{Critical Legal Theories}

Although critical legal theorists do not state that law is a direct instrument of the ruling class, their censorious analyses, in large measure, echo instrumentalism. For example, Critical Legal Studies scholars think that law is a source of power for the elites who try to define rights in a way to reinforce their wealth and privilege. ${ }^{94}$ Critical Race Theory advocates argue that law is used to perpetuate racial domination, ${ }^{95}$ whereas Critical Feminists think that law is employed to maintain a patriarchal society. ${ }^{96}$ In other words, critical legal theorists believe that law is used to create, perpetuate and advance the interests of the dominant social groups.

\section{Encapsulation}

In sum, it has been argued that law is closely connected with culture and social values (a reflection of society); is designed to cement a differentiated society (a social adhesive); or is employed to achieve political or social purposes (a political instrument). Nonetheless, some scholars question the validity of these claims or recommend further in-depth inquiry. For instance, Alan Watson maintained that although social values may influence lawmakers and social circumstances may affect the implementation of transplanted legal rules and institutions, it is legal culture that determines the developments of law, which has a life and vitality of its own. ${ }^{97}$ Against the pervasive presuppositions that law, being

\footnotetext{
91 Marx and Engels (2012), 74-116.

92 ibid.

93 David and Brierly (1978), 254-255.

94 Gordon (1990), 419.

95 Crenshaw et al. (1995), xxv.

96 Polan (1993).

97 Watson (1978), 314-315.
} 
derived from the custom and morality of society, is a mirror of society, and that law functions to maintain social order, Tamanaha posed two questions: (1) to what extent is law a mirror of prevailing customs and morals?. and (2) to what extent does law contribute to the maintenance of social order?. ${ }^{98}$ To unfold the evolutionary myth and the social contract myth, Tamanaha proposed a different genesis story: the principal object of the rulers is to maintain their wealth and power, but existing customs are allowed to remain in effect so long as these customs do not conflict with their interests and rules imposed by them. ${ }^{99}$ In that case, there is no gradual evolutionary differentiation of society leading to the emergence of law, and a system of laws is imposed on the defeated to consolidate the conqueror's rule. ${ }^{100}$ As such, state law need not have any connection with the society to which it is attached and does not necessarily mirror the society's customs or moral values. ${ }^{101}$

Despite its instrumentality, law can also be used to effect social changes as well as political and economic reforms. For example, the government may enact legislation to improve the lot of workers with disabilities or to eliminate racial and gender discriminations. Edward Palmer Thompson argued that law is not merely an instrument of class domination, but that it is a form of mediation between and within the classes. ${ }^{102}$ The function of law is not only to serve power and wealth, but also to impose effective inhibitions on power and to subject the ruling class to its own rules. ${ }^{103}$ In truth, law can be used to achieve social justice. Austin Sarat explained that law is 'the political forces working, albeit modestly, to expand the rights and redistribute wealth and power'. ${ }^{104}$ Accordingly, law can be an agent of both social control and social change.

Most scholars of 'law and society' regard law as a set of institutional practices that have, in conjunction with other social institutions, developed and evolved over time. Laurence Friedman said that 'legal systems do not float in some cultural void, free of space and time and social

\footnotetext{
98 Tamanaha (2001), 231.

99 ibid., 65.

100 ibid., 69.

101 ibid., 71.

102 Thompson (1975), 266.

103 ibid.

104 Sarat (2004), 3.
} 
context; necessarily, they reflect what is happening in their own societies'. ${ }^{105}$ Hence, law cannot be understood or interpreted without reference to the pertinent time and place, completely oblivious of the historical period and detached from the relevant social, cultural, political and economic contexts. As society develops, so do the role and function of law in society. Legal developments also have an impact on social progress, and social changes entail the enactment and amendment of relevant laws. The present study, therefore, examines the dynamic and interactive relationship between 'law' and 'society' in Chinese societies over time in the light of the pertinent historical, social, political and economic circumstances. Even so, the present study is not undertaken to substantiate or refute the mirror thesis.

\section{CHINESE LAW IN CONTEXT}

Notwithstanding a plethora of jurisprudential and socio-legal theories, it is noteworthy that theories on the interplay between 'law' and 'society' have been developed primarily by scholars in the Anglo-American and European societies, whose cultures, social structures, and ways of thinking have inevitably affected what social phenomena they heed and how they interpret and comprehend social occurrences. Against this backdrop, the application of the currently prevalent socio-legal theories to the study of Asian societies without reservations is problematic, let alone the question of whether it is judicious to do so. The formulation of research questions based on theories derived from the Anglo-American and European perspectives and the selection of social phenomena to corroborate the hidden assumptions and preconceived notions of a researcher are analogous to finding the desired objects and putting them in the pigeonholes or compartments of an analytical frame, whether such a frame is linear, circular or spiral. In this way, the study of China will add another example to reinforce existing socio-legal theories but will not foster the formulation of innovative theories for studying Asian countries. Nonetheless, a ground-breaking paradigm shift in relation to the sociolegal study of Asian societies is yet to occur.

To avoid the application of potentially inappropriate theories, the present study endeavours to examine the dynamic and interactive relationship between 'law' and 'society' in China without applying a specific

105 Friedman (1996), 72. 
theoretical framework. In addition, theoretical constructs or methodological approaches conceptualized in words ending in 'ism', and valueladen antithetical words such as 'traditional' and 'modern', are kept to a minimum. However, since the overarching aim is to investigate the developments of law and the role of law in social governance from dynastic to contemporary China, the present study is, to an extent, an intellectual pursuit reminiscent of both functionalism and instrumentalism. In this regard, the term 'social governance', rather than 'social engineering' or 'social ordering', is employed because (1) the word 'governance' is more neutral than the word 'engineering', which often carries a connotation of manipulation; (2) the word 'governance' is a broader term than 'ordering', which often refers to the absence of chaos and presence of conformity; and (3) 'social governance' at the macro level is analogous to the term 'corporate governance', which concerns how a corporation should be run at the micro level, involving such elements as structure, power, administration, accountability, rights and duties. Moreover, 'social governance' here is broadly defined to include political governance. Indeed, these determinations are designed to prevent the reader from being predisposed to understand China on a selected path.

Nonetheless, to impart the findings of the present study and enhance its reading-worthiness, it is necessary to employ concepts, principles and wording, whether they are theoretical or merely common usage, to which the reader can relate. This is akin to the situation where, in the absence of an extensively used language such as English, or a set of common symbols such as musical notes, it will be very difficult, if not impossible, to exchange information or to perform a quintet. One caveat, though, is that the expression of a term or concept in a language other than the original one can be limited by the syntax and vocabulary of the foreign language. Despite the possibility of linguistic limits, the present study, in analysing 'law and society' in China, will employ common socio-legal concepts, principles and wording to communicate with the reader and disseminate its findings. This approach is conducive to the materialization of two desirable objectives of the present study - fostering increased international understanding and promoting constructive academic and cultural exchanges.

Despite the non-application of a specific theory, the present study will not be merely descriptive for three reasons. First, clear expositions of the interplay between 'law' and 'society' in Chinese societies of various historical periods will unfold the temporal and spatial dimensions of 'law and society'. Second, a sequential and progressive, rather than a piecemeal and disconnected, exposure to the interaction between 'law' and 'society' in China will enable the reader to obtain a more panoramic 
understanding of law and its evolution in China. Third, a study of 'law and society' in China with critical analyses and insightful findings will yield useful lessons on the role of law in social governance within the broader context of law-and-society research. In this light, the present study will not be devoid of contributions to existing scholarship.

In essence, the present study is a law-and-society analysis of the interplay between 'law' and 'society' in China, taking into consideration cultural, economic, political and historical factors. Although the present study does not individually apply the consensus theory or the conflict theory to examine the relationship between 'law' and 'society' in China, the central research question is what role the law has played in social governance in China at various historical times. As such, the present study can be deemed a longitudinal analysis of 'law and society' in China over several historical periods - the dynastic realm, the early republic, the initial era of the socialist republic, the subsequent decades of opening up and reform, and the present-day China. Moreover, although finer historical demarcations can be made within each epoch, the present study uses watersheds to divide the Chinese history into major periods.

Based on the salient features of the 'law and society' of each epoch, it should be possible not only to understand how 'law' and 'society' interact in various Chinese societies, but also to unlock commonalities, similarities, differences and continuities over time. Such an analysis may make it possible to glimpse the content of the prospective 'rule of law' with Chinese characteristics. Where it is warranted, the present study will also highlight similar or different issues and phenomena from the perspective of comparative law because latitudinal analyses between China and other societies will not only assist the reader in understanding China and his or her own country, but may also result in the discernment of common themes and useful insights about 'law and society' in general. It is also notable that decisions on what findings should be presented and how the information should be conveyed are derived mainly from the researcher's scholarly judgement. Accordingly, it is inevitable that any study will, whether to a small or large extent, be influenced by the researcher's own background, training and ideological values, but the reader is also free to agree or disagree with the researcher. 